\title{
Symptomatic isolated terminal ileal ulcers: etiology and clinical significance
}

\section{다)(요 $\odot$}

\author{
Authors \\ Varun Mehta ${ }^{1}$, Ankita Gupta ${ }^{1}$, Ramit Mahajan ${ }^{1}$, Vikram Narang $^{2}$, Vandana Midha ${ }^{3}$, Neena Sood ${ }^{2}$, Harpreet Kaur ${ }^{2}$, \\ Kirandeep Kaur4 ${ }^{4}$ Ajit Sood ${ }^{1}$
}

Institutions

1 Department of Gastroenterology, Dayanand Medical College, Ludhiana, Punjab, India

2 Department of Pathology, Dayanand Medical College, Ludhiana, Punjab, India

3 Department of Internal Medicine, Dayanand Medical College, Ludhiana, Punjab, India

4 Department of Pharmacology, Dayanand Medical College, Ludhiana, Punjab, India

submitted 14.7.2016

accepted after revision: 23.12.2016

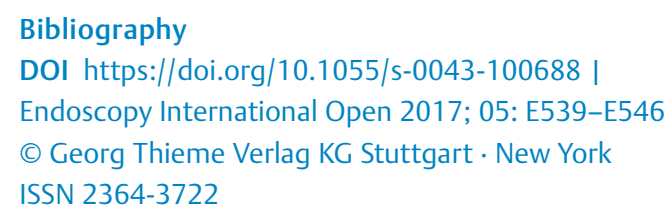

Corresponding author

Ramit Mahajan, MD DM, Department of Gastroenterology, Dayanand Medical College \& Hospital, Ludhiana, Punjab, India

Fax: +91-161-2302620

mahajan.ramit@gmail.com

\section{ABSTRACT}

Background With an increasing number of ileal intubations, isolated terminal ileal ulcers (ITIU) are frequently found during colonoscopies. The present study aimed at studying the etiology and clinical significance of these ulcers in patients having gastrointestinal symptoms.

Methods This was a prospective observational study performed on consecutive patients who underwent ileocolonoscopy for various gastrointestinal symptoms between 1 January 2014 and 31 December 2014. Clinical, endoscopic, and histological findings of patients with ITIUs were assessed to determine the etiology and they were treated accordingly. Symptom resolution was assessed within 3-6 months of initial diagnosis, and colonoscopy was repeated for consenting patients.

Results Among 74 (4.9\%) of 1497 patients who had ITIUs on ileocolonoscopy, 41 (55.4\%) had specific etiologies on initial testing. After 3-6 months follow-up, definitive diagnosis was ascertained in $44(59.5 \%)$ patients [Crohn's disease (CD): 19 (25.7\%), NSAID-induced ulcers: 11 (14.9\%), intestinal tuberculosis (ITB): 9 (12.2\%), and eosinophilic enteritis: $5(6.8 \%)$ ], and 30 patients $(40.5 \%)$ had nonspecific ulcers. After treatment, symptomatic and endoscopic resolution were noted in 55/60 patients (91.7\%) and 28/36 patients $(77.8 \%)$, respectively. Of 5/60 patients who remained symptomatic, three were initially diagnosed with nonspecific ulcers and two with CD, and they were finally diagnosed with CD and ITB respectively, and treated accordingly.

Conclusions In patients with gastrointestinal symptoms, more than half of the ITIUs have specific etiologies, and timely diagnosis and appropriate treatment can prevent serious complications. Nonspecific ulcers can be managed with symptomatic treatment, but need close monitoring and re-evaluation in the case of persistence of symptoms.

\section{Introduction}

Ileoscopy at colonoscopy is a simple maneuver, which confirms the completeness of the procedure and improves the diagnostic yield. With an increasing number of ileal intubations, it is not uncommon to detect single or multiple ulcers in the terminal ileum [1-3]. In patients with ileal and/or ileocolonic involvement on imaging modalities, these ulcers are always of clinical significance and help in establishing the diagnosis. On the other hand, most terminal ileal ulcers detected incidentally in asymptomatic patients can be ignored [4], but the etiology and clini- cal significance of these lesions in patients with abdominal symptoms have not been defined. The diagnosis of the specific cause of ileitis is important, because misdiagnosis may result in delays or errors in patient management.

The present study aimed at studying the etiology and clinical outcomes of ITIUs detected on ileocolonoscopy in patients with gastrointestinal symptoms at a tertiary care center in North India. 
- Table 1 Diagnostic parameters used and initial treatment given.

\begin{tabular}{|c|c|c|c|c|}
\hline Diagnosis & Colonoscopy & Histology & Others & Treatment given \\
\hline $\begin{array}{l}\text { Crohn's disease: } \\
\text { ECCO guidelines } \\
{[18]}\end{array}$ & ITIUs and/or erosions & $\begin{array}{l}\text { Focal/patchy chronic lymphoplas- } \\
\text { macytic inflammation, irregular } \\
\text { villus architecture, crypt distor- } \\
\text { tion, granuloma }\end{array}$ & $\begin{array}{l}\text { No response/worsening/worsening after } \\
\text { initial improvement with standard anti- } \\
\text { tubercular treatment AND subsequent } \\
\text { clinical response to oral steroids [19] }\end{array}$ & $\begin{array}{l}\text { Pentasa and } \\
\text { Budesonide }\end{array}$ \\
\hline $\begin{array}{l}\text { Intestinal tuber- } \\
\text { culosis }[20,21]\end{array}$ & ITIUs and/or erosions & $\begin{array}{l}\text { Confluent, caseating granulomas } \\
\text { containing acid fast bacilli and } \\
\text { surrounded by a lymphoid cuff }\end{array}$ & Response to anti-tubercular treatment & $\begin{array}{l}\text { Anti-tubercular } \\
\text { therapy }\end{array}$ \\
\hline $\begin{array}{l}\text { NSAID-induced } \\
\text { ulcers [22] }\end{array}$ & ITIUs and/or erosions & No specific histological features & $\begin{array}{l}\text { History of NSAID intake AND symptom re- } \\
\text { solution with cessation of NSAIDs, after } \\
\text { exclusion of other causes (malignancy, } \\
\text { inflammatory bowel disease, and infec- } \\
\text { tious disease) }\end{array}$ & $\begin{array}{l}\text { Withdrawal of } \\
\text { NSAIDs }\end{array}$ \\
\hline $\begin{array}{l}\text { Eosinophilic } \\
\text { enteritis } \\
{[23,24]}\end{array}$ & $\begin{array}{l}\text { ITIUs and/or nodular } \\
\text { or polypoid ileal mu- } \\
\text { cosa, erythema, or } \\
\text { erosions }\end{array}$ & $\begin{array}{l}\text { More than } 30 \text { eosinophils per high } \\
\text { power field on histopathology }\end{array}$ & $\begin{array}{l}\text { After excluding other causes of eosino- } \\
\text { philia (infections, parasitic infestation, } \\
\text { inflammatory bowel disease, celiac dis- } \\
\text { ease, connective tissue disorders) }\end{array}$ & $\begin{array}{l}\text { Six-Food Elimina- } \\
\text { tion Diet and/or } \\
\text { steroids }\end{array}$ \\
\hline $\begin{array}{l}\text { Nonspecific } \\
\text { ulcers [4] }\end{array}$ & ITIUs and/or erosions & $\begin{array}{l}\text { Focal cryptitis, crypt distortion, } \\
\text { acute or chronic inflammatory } \\
\text { cells without granulomas, basal } \\
\text { plasmacytosis }\end{array}$ & & $\begin{array}{l}\text { Symptomatic } \\
\text { treatment }\end{array}$ \\
\hline
\end{tabular}

\section{Material and methods}

\section{Study design}

This prospective single center observational study was performed by evaluating consenting consecutive patients who underwent ileocolonoscopy for gastrointestinal symptoms (abdominal pain, altered bowel habits, overt or occult gastrointestinal bleed, fever, and weight loss) at the Endoscopy unit in the Department of Gastroenterology, Dayanand Medical College and Hospital, Ludhiana, India from 1 January 2014 through 31 December 2014. Patients who showed single or multiple ITIUs as the sole endoscopic abnormality were recruited prospectively. Patients who refused to consent, had incomplete colonoscopy (due to colonic strictures or growths), colonic or ileocecal ulcers and those with abnormalities on abdominal imaging (CT/MRI) were excluded. The study protocol was approved by the institutional ethics committee.

\section{Data collection}

For recruited patients, the data collected included demographic data (including age and gender), clinical features and their duration, history of NSAID intake, laboratory investigations (including complete blood counts, inflammatory markers such as erythrocyte sedimentation rate (ESR) and C-reactive protein (CRP), serum protein and albumin, antibodies to tissue transglutaminase, serum vitamin B12, D-xylose test, anti-human immunodeficiency virus (HIV) antibodies, anti nuclear antibodies (ANA), stool examination for parasites including special stains for opportunistic pathogens, stool culture, chest radiograph, Mantoux test and special tests such as tissue polymerase chain reaction (PCR) for tuberculosis (TB) or cytomegalovirus where required), colonoscopic and histological findings, initial diag- nosis and treatment given. The patients were followed up clinically and a repeat colonoscopy with biopsies was done after 3 to 6 months, if the patient gave consent.

Colonoscopy was done with video-colonoscope (CF-Q160 L, Olympus Medical Systems Corp, Tokyo, Japan) under conscious sedation after preparation with polyethylene glycol electrolyte lavage solution. In patients with ITIUs, biopsies (minimum four in number) were taken from the ulcer margins and base, and sent in formalin for histopathology. The parameters used for arriving at a diagnosis of ITIUs are summarized in $>$ Table 1 . Patients diagnosed with ITIU were started on treatment based on the etiology as determined by clinical, endoscopic, and histological findings; these are also summarized in $>$ Table 1.

The patients were followed up for improvement or resolution of symptoms within 3-6 months of the initial diagnosis, and colonoscopy was repeated for consenting patients.

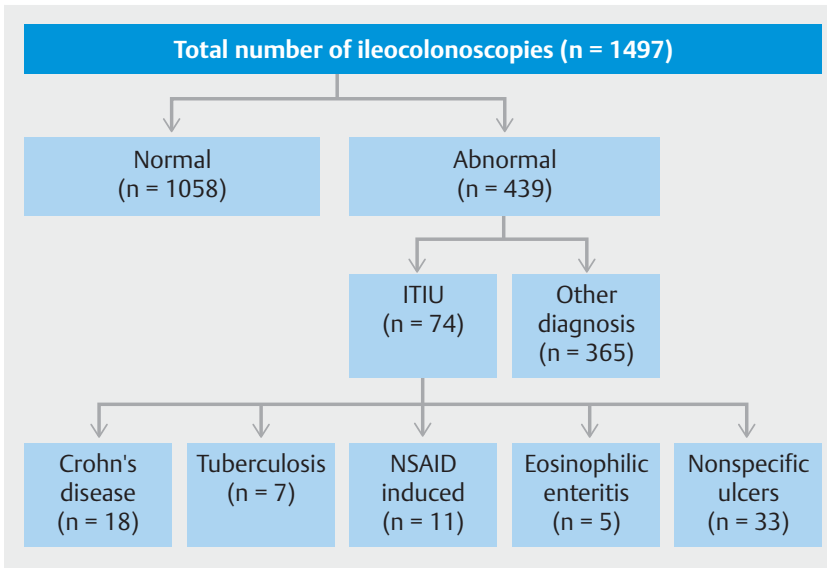

Fig. 1 Patient flow chart. 
- Table 2 Demographic details, clinical presentation, laboratory parameters, colonoscopic, and histologic findings of patients sorted according to diagnosis.

\begin{tabular}{|c|c|c|c|c|c|c|c|}
\hline & $\begin{array}{l}\text { Crohn's dis- } \\
\text { ease }(n=18)\end{array}$ & $\begin{array}{l}\text { Tuberculosis } \\
(n=7)\end{array}$ & $\begin{array}{l}\text { NSAIDs } \\
(n=11)\end{array}$ & $\begin{array}{l}\text { Eosinophilic } \\
\text { enteritis } \\
(n=5)\end{array}$ & $\begin{array}{l}\text { Nonspecific } \\
\text { ulcers } \\
(n=33)\end{array}$ & Total $(n=74)$ & $\begin{array}{l}P \text {-value } \\
\text { (Chi- } \\
\text { squared } \\
\text { test) }\end{array}$ \\
\hline \multicolumn{8}{|l|}{ Demographics } \\
\hline Age, mean $\pm S D$, years & $32.28 \pm 10.95$ & $37.29 \pm 12.47$ & $40.36 \pm 16.44$ & $42.2 \pm 2.86$ & $39.36 \pm 16.48$ & $37.78 \pm 14.43$ & - \\
\hline Gender, M/F & $15 / 3$ & $6 / 1$ & $5 / 6$ & $1 / 4$ & $28 / 5$ & $55 / 19$ & - \\
\hline $\begin{array}{l}\text { Median symptom } \\
\text { duration, months }\end{array}$ & 67.2 & 11.6 & 2.4 & 3.5 & 3.1 & 17.48 & - \\
\hline \multicolumn{8}{|c|}{ Clinical presentation and laboratory parameters } \\
\hline Pain & $10(55.6 \%)$ & $7(100 \%)$ & $6(54.5 \%)$ & $3(60 \%)$ & $18(54.5 \%)$ & $44(59.5 \%)$ & 0.255 \\
\hline Diarrhea & $15(83.3 \%)$ & $5(71.4 \%)$ & $10(90.9 \%)$ & $4(80 \%)$ & $23(69.7 \%)$ & $57(77 \%)$ & 0.6 \\
\hline Constipation & $2(11.1 \%)$ & $2(28.6 \%)$ & $2(18.2 \%)$ & $1(20 \%)$ & $10(30.3 \%)$ & $17(23 \%)$ & 0.605 \\
\hline $\begin{array}{l}\text { Gastrointestinal } \\
\text { bleeding (overt) }\end{array}$ & $3(16.7 \%)$ & $0(0 \%)$ & $4(36.4 \%)$ & $0(0 \%)$ & $0(0 \%)$ & $7(9.5 \%)$ & $0.005^{1}$ \\
\hline $\begin{array}{l}\text { Gastrointestinal } \\
\text { bleeding (occult) }\end{array}$ & $1(5.6 \%)$ & $0(0 \%)$ & $0(0 \%)$ & $0(0 \%)$ & $5(15.2 \%)$ & $6(8.1 \%)$ & 0.357 \\
\hline Fever & $4(22.2 \%)$ & $3(42.9 \%)$ & $3(27.3 \%)$ & $1(20 \%)$ & $3(9.1 \%)$ & $14(18.9 \%)$ & 0.256 \\
\hline Weight loss & $9(50 \%)$ & $5(71.4 \%)$ & $3(27.3 \%)$ & $2(40 \%)$ & $9(27.3 \%)$ & $28(37.8 \%)$ & 0.159 \\
\hline Oral ulcers & $5(27.8 \%)$ & $1(14.3 \%)$ & $0(0 \%)$ & $0(0 \%)$ & $0(0 \%)$ & $6(8.1 \%)$ & $0.007^{1}$ \\
\hline $\begin{array}{l}\text { Anemia }(\mathrm{Hb}<12 \mathrm{~g} / \mathrm{dL} \\
\text { for women; }<13 \mathrm{~g} / \mathrm{dL} \\
\text { for men) }\end{array}$ & $3(16.7 \%)$ & $2(28.6 \%)$ & $4(36.4 \%)$ & $0(0 \%)$ & $0(0 \%)$ & $9(12.2 \%)$ & 0.009 \\
\hline $\begin{array}{l}\text { Elevated CRP levels } \\
\text { (Normal: } 0-10 \mathrm{mg} / \mathrm{L} \text { ) }\end{array}$ & $6(33.3 \%)$ & $3(42.9 \%)$ & $0(0 \%)$ & $0(0 \%)$ & $0(0 \%)$ & $9(12.2 \%)$ & $<0.001^{1}$ \\
\hline \multicolumn{8}{|l|}{ Colonoscopic findings } \\
\hline \multicolumn{8}{|l|}{ Ulcer size } \\
\hline$<5 \mathrm{~mm}$ & $10(55.6 \%)$ & $6(85.7 \%)$ & $11(100 \%)$ & $5(100 \%)$ & $22(66.7 \%)$ & $54(73 \%)$ & \multirow{2}{*}{$0.42^{1}$} \\
\hline$>5 \mathrm{~mm}$ & $8(44.4 \%)$ & $1(14.3 \%)$ & $0(0 \%)$ & $0(0 \%)$ & $11(33.3 \%)$ & $20(27 \%)$ & \\
\hline \multicolumn{8}{|l|}{ Ulcer number } \\
\hline 1 & $0(0 \%)$ & $0(0 \%)$ & $0(0 \%)$ & $0(0 \%)$ & $10(30.3 \%)$ & $10(13.5 \%)$ & \multirow{3}{*}{$<0.001^{1}$} \\
\hline $2-3$ & $8(44.4 \%)$ & $4(57.1 \%)$ & $2(18.2 \%)$ & $0(0 \%)$ & $2(6.1 \%)$ & $16(21.6 \%)$ & \\
\hline Multiple & $10(55.6 \%)$ & $3(42.9 \%)$ & $9(81.8 \%)$ & $5(100 \%)$ & 21 (63.6\%) & 48 (64.9\%) & \\
\hline Nodules & $0(0 \%)$ & $3(42.9 \%)$ & $0(0 \%)$ & $(0 \%)$ & $0(0 \%)$ & $3(4.1 \%)$ & $<0.001^{1}$ \\
\hline Erosions & $8(44.4 \%)$ & $3(42.9 \%)$ & $5(45.5 \%)$ & $0(0 \%)$ & $0(0 \%)$ & $16(21.6 \%)$ & $<0.001^{1}$ \\
\hline Strictures & $0(0 \%)$ & $1(14.3 \%)$ & 1 (9.1\%) & $0(0 \%)$ & $0(0 \%)$ & $2(2.7 \%)$ & 0.145 \\
\hline
\end{tabular}

\section{Statistical analysis}

Continuous data were expressed as mean \pm SD or median as appropriate. Categorical variables were expressed as percentages. Chi-squared test was used to compare various parameters of demographic information, clinical presentation, colonoscopic findings, laboratory values, and histological features with the initial clinical diagnosis to evaluate the presence of any pattern.
$P$-values of $<0.05$ were considered to be statistically significant. SPSS software version 22 was used for data analysis.

\section{Results}

The patient disposition is summarized in $>$ Fig. 1 .

A total of 1497 ileocolonoscopies were performed for various indications between 1 January 2014 and 31 December 2014. 
- Table 2 (Continuation)

\begin{tabular}{|c|c|c|c|c|c|c|c|}
\hline & $\begin{array}{l}\text { Crohn's dis- } \\
\text { ease }(n=18)\end{array}$ & $\begin{array}{l}\text { Tuberculosis } \\
(n=7)\end{array}$ & $\begin{array}{l}\text { NSAIDs } \\
(n=11)\end{array}$ & $\begin{array}{l}\text { Eosinophilic } \\
\text { enteritis } \\
(n=5)\end{array}$ & $\begin{array}{l}\text { Nonspecific } \\
\text { ulcers } \\
(n=33)\end{array}$ & Total $(n=74)$ & $\begin{array}{l}\text { P-value } \\
\text { (Chi- } \\
\text { squared } \\
\text { test) }\end{array}$ \\
\hline \multicolumn{8}{|l|}{ Histology } \\
\hline $\begin{array}{l}\text { Villi appearance } \\
\text { (normal) }\end{array}$ & $15(83.3 \%)$ & $7(100 \%)$ & $11(100 \%)$ & $5(100 \%)$ & $33(100 \%)$ & $71(95.9 \%)$ & \multirow{2}{*}{$0.45^{1}$} \\
\hline $\begin{array}{l}\text { Villi appearance } \\
\text { (blunted) }\end{array}$ & $3(16.7 \%)$ & $0(0 \%)$ & $0(0 \%)$ & $0(0 \%)$ & $0(0 \%)$ & $3(4.1 \%)$ & \\
\hline Epithelial erosion/ulcer & $7(38.9 \%)$ & $1(14.3 \%)$ & $7(63.6 \%)$ & $2(40 \%)$ & $11(33.3 \%)$ & $28(37.8 \%)$ & 0.281 \\
\hline Cryptitis & $15(83.3 \%)$ & $0(0 \%)$ & $2(18.2 \%)$ & $3(60 \%)$ & $0(0 \%)$ & $20(27 \%)$ & $<0.001^{1}$ \\
\hline Crypt distortion & $7(38.9 \%)$ & $0(0 \%)$ & $0(0 \%)$ & $0(0 \%)$ & $0(0 \%)$ & $7(9.5 \%)$ & $<0.001^{1}$ \\
\hline Crypt abscess & $3(16.7 \%)$ & $0(0 \%)$ & $0(0 \%)$ & $0(0 \%)$ & $0(0 \%)$ & $3(4.1 \%)$ & $0.45^{1}$ \\
\hline Eosinophilia & $3(16.7 \%)$ & $0(0 \%)$ & $4(36.4 \%)$ & $5(100 \%)$ & $3(9.1 \%)$ & $15(20.3 \%)$ & $<0.001^{1}$ \\
\hline Granuloma & $3(16.7 \%)$ & $4(57.1 \%)$ & $0(0 \%)$ & $0(0 \%)$ & $0(0 \%)$ & $7(9.5 \%)$ & $<0.001^{1}$ \\
\hline
\end{tabular}

Patients in whom the ileum was not intubated due to distal obstruction or technical problems were excluded. Abnormal findings were seen in 439 (29.3\%) of the patients, and ITIUs were seen in 74 patients from the 1497 ileocolonoscopies (4.9\%). Abdominal imaging (CT/MRI) for these patients was normal. Specific etiologies such as Crohn's disease, intestinal tuberculosis, NSAID enteropathy, and eosinophilic enteritis were established in more than half of these patients.

The demographic and other details of the patients are summarized in $>$ Table 2 . The mean age of the patients with ITIUs was $37.78 \pm 14.43$ years, and 55 out of 74 patients were male. The median duration of symptoms was longest in Crohn's disease (5.6 years) and shortest in NSAID induced ulcers. The three most common presenting symptoms among all patients with ITIUs included chronic diarrhea (77\%), pain (59.5\%), and weight loss (37.8\%).

CRP level elevation and oral ulcers were only observed in patients with Crohn's disease and tuberculosis ( $P=0.007$ for oral ulcers; $P<0.001$ for elevated CRP levels). Overt gastrointestinal bleeding was encountered more commonly in patients having Crohn's disease and NSAID-induced ulcers $(P=0.005)$. The pattern of distribution of other symptoms was not statistically significant: anemia was encountered in patients having Crohn's disease, TB, or NSAID-induced ulcers, and constipation and occult gastrointestinal bleeding were more often seen in patients with nonspecific ulcers. The small sample size and large number of diagnoses prevented us from performing a multivariate analysis.

Determining etiology of ITIUs based on endoscopic findings ( $\triangleright$ Fig.2) was difficult. Ulcers (100\%) and erosions (21.6\%) were the commonest ileoscopic findings. Three patients had mucosal nodularity (all had ITB) and two (one each with CD and ITB) had strictures. All patients with eosinophilic enteritis had multiple ulcers, and solitary ulcers were only seen in patients having nonspecific ulcers $(P<0.001)$.

Only patients with Crohn's disease demonstrated blunted villi $(P=0.45)$, cryptitis, crypt distortion $(P<0.001$ for both), and crypt abscesses $(P=0.45)$. Granulomas were seen in seven patients, four of whom were treated as ITB and three as Crohn's disease $(P<0.001)$. Of the 15 patients with eosinophilic infiltrate, three had histology suggestive of $C D$, four had a history of NSAIDs, and five were diagnosed to have eosinophilic enteritis $(P<0.001)(>$ Fig. 3$)$.

Out of the initial 74 patients, 60 returned for follow-up 3-6 months after treatment initiation, and the initial symptoms had resolved in 55 (91.7\%) of these 60 patients. The five patients who had persistent symptoms (three treated as nonspecific ulcers, and two as Crohn's disease) underwent repeat ileocolonoscopy which revealed persistence of multiple ITIUs. The three patients who were initially diagnosed to have nonspecific ileitis had now developed villous abnormalities, cryptitis, crypt abscesses (one had granulomas), and were diagnosed and treated as Crohn's disease. Two patients who were treated as Crohn's disease (in view of chronic inflammatory infiltrates in lamina propria with cryptitis, no evidence of granulomas or acid fast bacilli) continued to be symptomatic (pain in abdomen, chronic diarrhea, anemia, no fever). Repeat evaluation showed persistence of ITIUs and biopsies revealed granulomas suggestive of tuberculosis. These patients were started on anti-tubercular treatment. In addition to these five patients, repeat ileocolonoscopy was also performed in consenting patients with symptom resolution $(n=31)$, and TIU resolution was observed in 28 of the 36 patients $(77.8 \%)$. The follow-up details are summarized in - Table 3. 

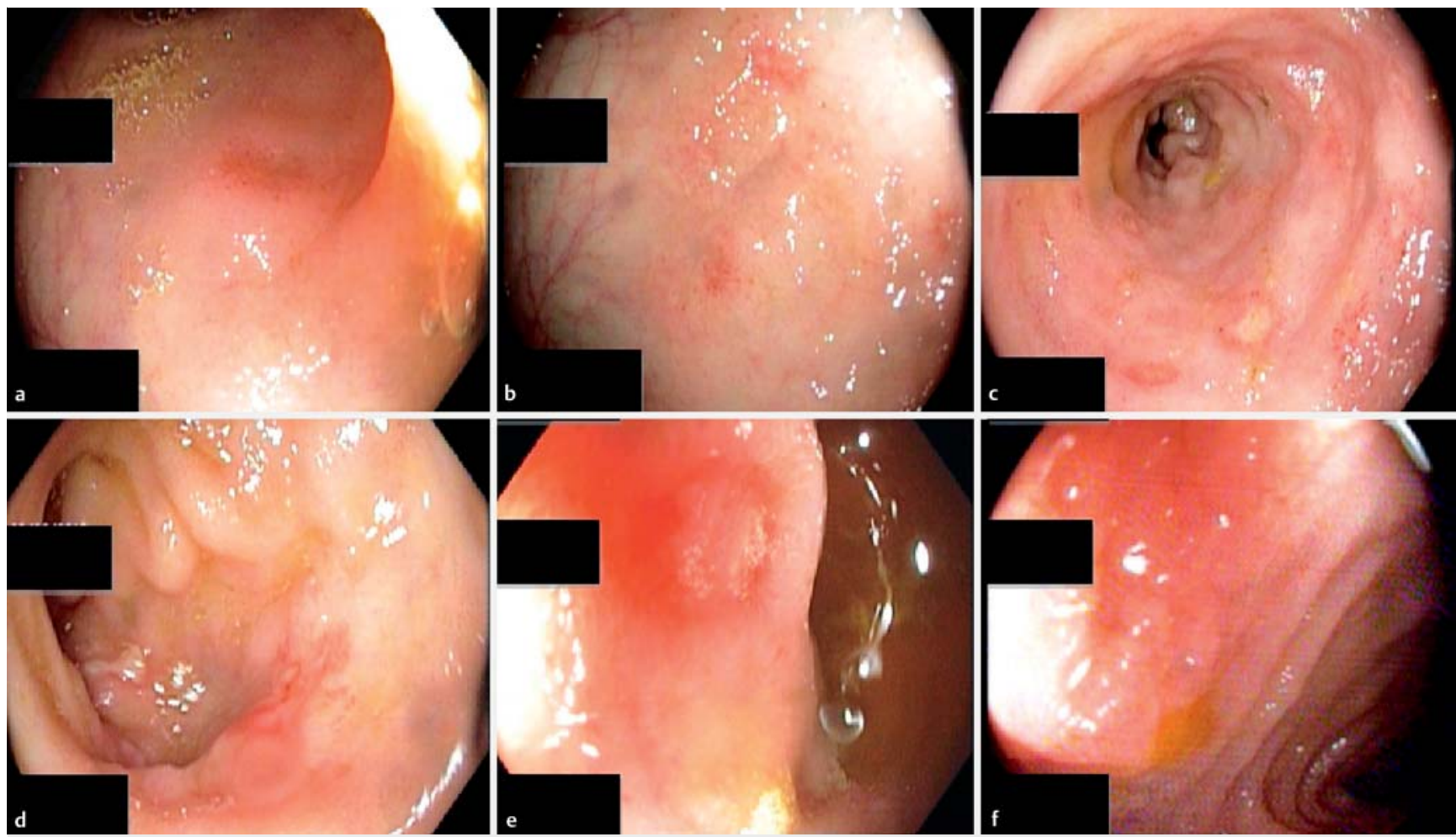

Fig. 2 Endoscopic findings in patients with isolated terminal ileal ulcers. lleoscopy images showing erosions (a,b); ulcers (c-e), and mucosal nodularity (f).

\section{Discussion}

Though there are studies describing the clinical course and follow up of asymptomatic terminal ileitis [4-6], data on symptomatic terminal ileal ulcers is sparse. This study was conducted with an aim to understand the etiology and clinical outcomes of ITIU detected on ileocolonoscopy in patients with gastrointestinal symptoms. We found that 74 out of 1497 (4.9\%) patients who underwent ileocolonoscopy had ITIUs, and specific etiologies could be ascertained initially in 41 (55.4\%) of these 74 patients. By the end of the follow-up period, a definitive diagnosis was made in a total of $44(59.5 \%)$ patients. The final tally of diagnoses was Crohn's disease: 19 (25.7\%), NSAID-induced ulcers: 11 (14.9\%), intestinal tuberculosis: 9 (12.2\%), eosinophilic enteritis: $5(6.8 \%)$, and nonspecific ulcers: 30 $(40.5 \%)$. None of our patients with gastrointestinal symptoms and ITIUs had vasculitis, lymphomas or malignancies.

Out of the various clinical presentations considered, the three commonest symptoms were pain, diarrhea, and weight loss, irrespective of the final diagnosis. In addition to these, oral ulcers and elevated CRP levels were more commonly seen in Crohn's disease or tuberculosis, while overt gastrointestinal bleeding was seen in patients with NSAID enteropathy and Crohn's disease. Our findings were different from a recent study from India [7] where patients with Crohn's disease or tuberculosis had significantly more symptoms than those with nonspecific ulcers. In patients with nonspecific ulcers, $89.5 \%$ of the symptomatic patients in their study had specific pathology such as tuberculosis/Crohn's disease, diagnosed based on ileal thickening on imaging. Thirty-eight percent of their patients with nonspecific ulcers were asymptomatic and most of those (91\%) were managed symptomatically [7]. On the other hand, our series included symptomatic patients with normal imaging and $40.5 \%$ of these had nonspecific ulcers, which responded to symptomatic management.

On ileocolonoscopy, all ITIUs appeared alike, though ulcers with specific etiologies were multiple, and single ulcers were all of a nonspecific etiology. Ileal nodules, erosions, and strictures were only noted in patients with Crohn's disease, tuberculosis, or NSAID enteropathy. Histological diagnosis was fairly accurate in most of the patients and they responded favorably to the treatment provided. The most frequent specific diagnosis for ITIUs obtained in our study was Crohn's disease. This is consistent with previously reported series $[8,9]$. In countries such as India where tuberculosis continues to be highly prevalent, differentiating Crohn's disease from tuberculosis is a challenging task. Both of these diseases have similar features such as weight loss, CRP elevation, and granulomas on histological examination. Two of our patients diagnosed with Crohn's continued to have symptoms and were diagnosed with tuberculosis on follow up. Testing these patients with tissue TB-PCR or Interferon gamma release assays (Quantiferon TB gold) may have helped in increasing the diagnostic yield in these patients [10]. Nonspecific terminal ileal ulcers were noted in 33 of the 74 patients $(44.6 \%)$. Most of these $(88.9 \%)$ responded to symptomatic management and $84 \%$ had endoscopic resolution on follow-up, thus highlighting the fact that nonspecific terminal ileal ulcers have a benign clinical course and are not associated 


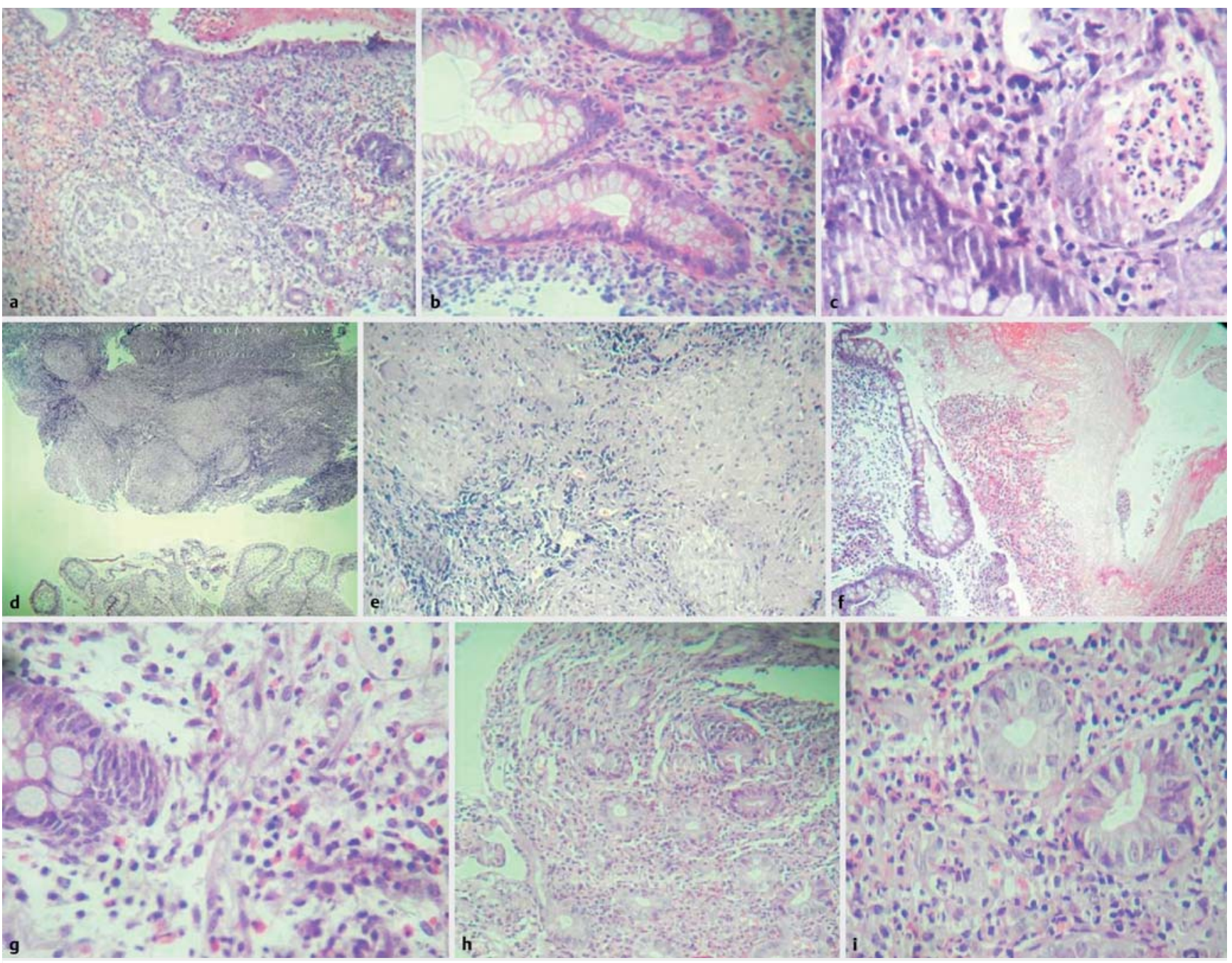

- Fig. 3 Histological findings in patients with isolated terminal ileal ulcers. Crohn's disease (a-c): a lleal ulceration with granulomatous reaction in the lamina propria (H\&E, $100 \times$ ); b Crypt distortion (H\&E, 400×); c Crypt abscess (H\&E, $400 \times$ ). Tuberculosis (d,e): d Normal villous pattern with extensive granulomatous reaction in one of the biopsy samples (H\&E, 100×); e Epithelioid cell granulomas with Langhans giant cell reaction and necrosis (H\&E, 200 $\times$ ); Eosinophilic ileitis (f,g): $\mathbf{f}$ lleum biopsy showing ulceration with inflammatory granulation predominantly comprised of eosinophils (H\&E, 200×); $\mathbf{g}>30$ Eosinophils/HPF in the lamina propria (H\&E, $400 \times$ ); Nonspecific acute ileitis (h,i): $\mathbf{h}$ Erosion of the epithelium (H\&E, $200 \times)$; i Acute and chronic inflammation in the lamina propria, no cryptitis, no crypt abscess, no granuloma (H\&E, 400×).

- Table 3 Follow-up details of patients.

\begin{tabular}{|c|c|c|c|c|c|}
\hline Initial diagnosis & $\begin{array}{l}\text { Initial number } \\
\text { of patients }\end{array}$ & $\begin{array}{l}\text { Number of patients } \\
\text { followed up }\end{array}$ & $\begin{array}{l}\text { Symptom } \\
\text { resolution }\end{array}$ & $\begin{array}{l}\text { Number of patients with } \\
\text { colonoscopic follow-up }\end{array}$ & TIU resolution \\
\hline Crohn's disease & 18 & 14 & $12(85.7 \%)$ & 11 & $9(81.8 \%)$ \\
\hline Tuberculosis & 7 & 5 & $5(100 \%)$ & 2 & $0(0 \%)$ \\
\hline NSAIDs & 11 & 11 & $11(100 \%)$ & 1 & $1(100 \%)$ \\
\hline Eosinophilic enteritis & 5 & 3 & $3(100 \%)$ & 3 & $2(66.7 \%)$ \\
\hline Nonspecific ulcers & 33 & 27 & $24(88.9 \%)$ & 19 & $16(84.2 \%)$ \\
\hline Total & 74 & 60 & 55 (91.7\%) & 36 & $28(77.8 \%)$ \\
\hline
\end{tabular}

NSAIDs, non-steroidal anti-inflammatory drugs; TIU, terminal ileal ulcer. 
with any serious complications that may need surgical intervention. Similar findings were noted in a study from China [11], where seven patients were followed up for 7 years. Colonic lavage using polyethylene glycol (PEG) or sodium phosphate before colonoscopy can also cause aphthous ulcers in the intestines [12-14]. These ulcers are more commonly seen in patients prepared with sodium phosphate [12]. Though our patients were prepared with PEG, some of the nonspecific ulcers which resolved on follow-up could have been due to colonic lavage. Patients with NSAID enteropathy and eosinophilic enteritis had complete symptom resolution on follow-up.

Overall, complete symptom resolution was observed in 55 out of 60 patients $(91.7 \%)$ who returned for follow-up, and endoscopic resolution was found in 28 out of 36 patients $(77.8 \%)$ who consented to a repeat endoscopy. Only five out of the 60 follow-up patients did not report symptom resolution. Three of these were initially diagnosed as nonspecific ulcers and two patients with Crohn's disease, and they were finally diagnosed with Crohn's disease and tuberculosis, respectively, and treated accordingly. The use of newer surrogate markers of inflammation such as serum calprotectin $[15,16]$ and lactoferrin [17] in these nonspecific ulcers could have aided in early diagnosis of these diseases.

The limitations of our study include its small sample size, which prevented us from performing a multivariate analysis of the symptom profile predicting a diagnosis of ITIUs, and a relatively short-term follow up. We also did not include tissue TBPCR or fecal calprotectin in our diagnostic tests which would have been a valuable tool to help in the diagnosis of intestinal tuberculosis or inflammatory bowel disease.

To conclude, we have observed from our study that over half of the patients with symptomatic ITIUs may have specific etiologies, and hence require appropriate evaluation. Since colonoscopic findings alone cannot accurately predict the etiology, laboratory and histological examinations are definitely required. Pointers towards a diagnosis of Crohn's disease include elevation of CRP and histological demonstrations of blunted villi and crypt changes, whereas strictures and nodules on colonoscopy (which are not picked up on CT/MRI due to small size) and granulomas on histology point towards a diagnosis of intestinal tuberculosis. Accurate diagnosis will result in early initiation of appropriate treatment, which can prevent complications such as strictures, blood loss, and dissemination of TB to other organs. Patients with nonspecific histological findings can be managed symptomatically; however, they should be monitored closely and if symptoms persist on treatment, repeat endoscopy and histopathology should be considered within 3-6 months for confirmation of diagnosis.

\section{Acknowledgments}

The authors acknowledge the support of MarksMan Healthcare Solutions, Navi Mumbai in the editing of the manuscript.
Competing interests

None

References

[1] Shah RJ, Fenoglio-Preiser C, Bleau BL et al. Usefulness of colonoscopy with biopsy in the evaluation of patients with chronic diarrhea. Am J Gastroenterol 2001; 96: 1091 - 1095

[2] Börsch DG, Schmidt G. Endoscopy of the terminal ileum. Dis Colon Rectum 1985; 28: 499 - 501

[3] Yusoff IF, Ormonde DG, Hoffman NE. Routine colonic mucosal biopsy and ileoscopy increases diagnostic yield in patients undergoing colonoscopy for diarrhea. J Gastroenterol Hepatol 2002; 17: 276-280

[4] Chang H-S, Lee D, Kim JC et al. Isolated terminal ileal ulcerations in asymptomatic individuals: natural course and clinical significance. Gastrointest Endosc 2010; 72: 1226-1232

[5] Courville EL, Siegel CA, Vay T et al. Isolated asymptomatic ileitis does not progress to overt Crohn disease on long-term follow-up despite features of chronicity in ileal biopsies. Am J Surg Pathol 2009; 33: $1341-1347$

[6] dos Santos CHM. Ileal ulcer in asymptomatic individuals. Is this Crohn? J Coloproctol 2012; 32: 119-122

[7] Kedia S, Kurrey L, Pratap Mouli V et al. Frequency, natural course and clinical significance of symptomatic terminal ileitis. J Dig Dis 2016; 17: $36-43$

[8] Jeong SH, Lee KJ, Kim YB et al. Diagnostic value of terminal ileum intubation during colonoscopy. J Gastroenterol Hepatol 2008; 23: 51 55

[9] Cherian S, Singh P. Is routine ileoscopy useful? An observational study of procedure times, diagnostic yield, and learning curve Am J Gastroenterol 2004; 99: 2324-2329

[10] Amarapurkar DN, Patel ND, Amarapurkar AD et al. Tissue polymerase chain reaction in diagnosis of intestinal tuberculosis and Crohn's disease. J Assoc Physicians India 2004; 52: 863 - 867

[11] Wang W, Wang Z, Yang Y et al. Long-term follow-up of nonspecific small bowel ulcers with a benign course and no requirement for surgery: is this a distinct group? BMC Gastroenterol 2011; 11: 51

[12] Atkinson RJ, Save V, Hunter JO. Colonic ulceration after sodium phosphate bowel preparation. Am J Gastroenterol 2005; 100: 2603-2605

[13] Hixson L]. Colorectal ulcers associated with sodium phosphate catharsis. Gastrointest Endosc 1995; 42: $101-102$

[14] Zwas FR, Cirillo NW, el Serag HB et al. Colonic mucosal abnormalities associated with oral sodium phosphate solution. Gastrointest Endosc 1996; 43: $463-466$

[15] Waugh N, Cummins E, Royle P et al. Faecal calprotectin testing for differentiating amongst inflammatory and non-inflammatory bowel diseases: systematic review and economic evaluation. Health Technol Assess Winch Engl 2013; 17: XV-XIX

[16] Larsson G, Shenoy KT, Ramasubramanian R et al. High faecal calprotectin levels in intestinal tuberculosis are associated with granulomas in intestinal biopsies. Infect Dis Lond Engl 2015; 47: 137-143

[17] Kane SV, Sandborn WJ, Rufo PA et al. Fecal lactoferrin is a sensitive and specific marker in identifying intestinal inflammation. Am J Gastroenterol 2003; 98: 1309-1314

[18] Van Assche G, Dignass A, Panes ] et al. European Crohn's and Colitis Organisation (ECCO). The second European evidence-based Consensus on the diagnosis and management of Crohn's disease: Definitions and diagnosis. J Crohns Colitis 2010; 4: 7-27

[19] Munot K, Ananthakrishnan AN, Singla $V$ et al. Response to trial of antitubercular therapy in patients with ulceroconstrictive intestinal dis- 
ease and an eventual diagnosis of Crohn's disease. Gastroenterology 2011; 140: S159

[20] Logan VS. Anorectal tuberculosis. Proc R Soc Med 1969; 62: 1227 1230

[21] Paustian F. Tuberculosis of the intestine. In: Bockus HL, ed. Bockus gastroenterology.5th edn. Philadelphia: Saunders; 1995: 3304

[22] Hayashi Y, Yamamoto H, Taguchi H et al. Nonsteroidal anti-inflammatory drug-induced small-bowel lesions identified by double-bal- loon endoscopy: endoscopic features of the lesions and endoscopic treatments for diaphragm disease. J Gastroenterol 2009; 44: (Suppl. 19): $57-63$

[23] Lee M, Hodges WG, Huggins TL et al. Eosinophilic gastroenteritis. South Med J 1996; 89: 189 - 194

[24] Lee CM, Changchien CS, Chen PC et al. Eosinophilic gastroenteritis: 10 years experience. Am J Gastroenterol 1993; 88: 70-74 